\title{
Study on the effect of Anammox/Fe0coupling treatment of nitrate wastewater under neutral conditions
}

\author{
Bing Wang ${ }^{1}$; Bing Sun ${ }^{1 *}$; Yunlong Liu ${ }^{1}$; Lin Yang ${ }^{1}$ \\ ${ }^{1}$ School of Municipal and Environmental Engineering, Shenyang Jianzhu University, Shenyang Liaoning 110168, P.R.China;
}

\begin{abstract}
Batch experiments were conducted to explore the effect of Anammox bacteria on the nitrate reduction efficiency of $\mathrm{Fe}^{0}$ under neutral conditions and to analyze the ways of its enhancement. The effects of $\mathrm{Fe}^{2+}$ concentration on the activity of Anammox bacteria in the system were investigated by detecting the nitrate content in the system under neutral conditions. The upflow reactor was set to verify the possibility of stable operation of $\mathrm{Fe}^{0} / A n a m m o x$ system in continuous flow. The results showed that in neutral environment, Anammox bacteria can significantly promote the reduction of nitrate by $\mathrm{Fe}^{0}$, and the denitration rate can reach more than $75 \%$ under the dual biological and chemical effects. In the continuous flow system of nitrate reduction by $\mathrm{Fe}^{0} / \mathrm{Anammox}$ bacteria, the stable treatment period was about 7 days. Through regular replacement of iron powder, the denitration rate can be maintained at more than $75 \%$ for a long time, and the effluent $\mathrm{NH}_{4}{ }^{+}, \mathrm{NO}_{2}{ }^{-}$concentration is low. The treatment of nitrate wastewater by zero-valent iron as a reducing agent has been widely paid attention, but the treatment effect is seriously affected by $\mathrm{pH}$. Anammox bacteria were added to coupling with $\mathrm{Fe}^{0}$ can not only promote each other's reactivity to adapt to more non-ideal environment, but also reduce secondary pollution, which provides a new idea for the practical application of nitrate wastewater treatment.
\end{abstract}

\section{Introduction}

With the rapid development of industry and agriculture, nitrate wastewater has become a serious environmental pollution problem ${ }^{[1]}$. Excessive nitrate content in water will not only cause ecological damage such as eutrophication, but also produce nitrite intermediate products which will threaten human health. China is the largest producer and consumer of chemical fertilizer in the world, and the use of chemical fertilizer leads to serious groundwater pollution $^{[2]}$. Therefore, the efficient treatment of nitrate wastewater has become an important subject in the field of environment.

Although physical and chemical methods such as ion exchange and reverse osmosis are effective, they are not ideal methods due to the need for frequent regeneration of media. Iron powder is not only highly restorative but also cheap and readily available. Using iron as reducing agent to remove nitrate from water is a promising wastewater treatment technology. Zawaideh et al. ${ }^{[3]}$ found that iron powder can effectively and rapidly reduce nitrate under acidic conditions. However, when $\mathrm{pH}$ is between 6 and 8 , nitrate reduction rate decreases rapidly and is lower than $40 \%{ }^{[4]}$. This is because iron powder in neutral environment is easy to passivation, which affects its reaction ability. Therefore, in order to maintain a high denitration rate in the system, it is necessary to continuously add acid to maintain $\mathrm{pH}$, which not only increases the cost but also is not conducive to equipment maintenance. Besides, the low $\mathrm{pH}$ leads to the reduction of nitrate into a large amount of ammonia nitrogen, causing serious secondary pollution. Therefore, how to make iron powder still have the ability to efficiently remove nitrate in neutral environment has more practical significance $^{[5]}$.

Studies have shown that $\mathrm{Fe}^{2+} / \mathrm{Fe}^{0}$ has the potential to reduce $\mathrm{NO}_{3}{ }^{-}$under the action of Anammox bacteria ${ }^{[6]}$. In 2013, Oshiki ${ }^{[7]}$ found that $\mathrm{Fe}^{2+}$ can reduce nitrate to nitrite and ammonia in the Anammox system. Xing et al. ${ }^{[8]}$ found that the addition of anaerobic ammonium oxidation sludge can enhance the reduction of nitrate by $\mathrm{Fe}^{0}$. Therefore, coupling $\mathrm{Fe}^{0}$ with Anammox bacteria in neutral environment can not only improve the denitration rate through biological/chemical dual effects, but also achieve the effect of removing ammonia-nitrogen byproducts, which is an important research direction in the field of nitrate wastewater.

In this paper, batch experiments were set to investigate the concentration changes of $\mathrm{NO}_{3}{ }^{-}, \mathrm{NH}_{4}{ }^{+}$and $\mathrm{NO}_{2}{ }^{-}$in the reaction process, to explore the influence of Anammox bacteria on the reduction of nitrate by $\mathrm{Fe}^{0}$ under neutral temperature conditions. The possibility of long-term stable operation of $\mathrm{Fe} 0 /$ Anammox was explored by setting continuous flow experiment, which

*Corresponding author: 415494033@qq.com 
provided experimental data for the practical application of nitrate wastewater treatment.

\section{Materials and methods}

\subsection{Experimental equipment}

\subsubsection{Batch experiments}

A $110 \mathrm{~mL}$ anaerobic serum flask was used as the experimental device, and the constant volume of the culture medium was $100 \mathrm{~mL}$. Before the experiment, the serum bottle was aerated with $99 \%$ pure nitrogen for 30 minutes to remove the dissolved oxygen, and the bottle mouth was quickly sealed with rubber stopper and aluminum cap. The bottle was placed in a thermostatic oscillator that was protected from light, and the rotating speed was maintained at $100 \mathrm{rpm}$. During the reaction, continuous sampling and measurement were conducted.

\subsubsection{Continuous flow experiment}

An upflow reactor with an effective volume of $0.8 \mathrm{~L}$ was used in the experiment, and $80 \mathrm{mLanammox}$ sludge (MLVSS $=3000 \mathrm{mg} / \mathrm{L}$ ) was added. The inlet water was deoxygenated with nitrogen of $99.5 \%$ purity. The internal outlet pipe of the device was connected with non-woven fiber membrane to control the microorganism not to be discharged with the outlet water. The outer glass tube of the device was wrapped with opaque cloth to prevent the effect of light on the activity of iron bacteria. The reactor was controlled at $32^{\circ} \mathrm{C}$ by heating the water tank.

\subsection{Inoculation sludge and experimental water quality}

The inoculated sludge used in this paper was Anammox sludge, which was taken from the laboratory Anammox reactor which had been in good operation for a long time. The sludge had good properties and was brick red. The simulated wastewater used in the experiment was manually configured, and its main components were: $\mathrm{NaNO}_{3}, \mathrm{KHCO}_{3}, \mathrm{KH}_{2} \mathrm{PO}_{4}$, trace elements (including $\left.\mathrm{CaCl}_{2} \cdot 2 \mathrm{H}_{2} \mathrm{O}, \mathrm{NaCl}, \mathrm{MgSO}_{4} \cdot 7 \mathrm{H}_{2} \mathrm{O}, \mathrm{KCl}\right)$. The $\mathrm{Fe}^{0}$ used in this experiment was iron powder with particle size of 150um, which is activated before use. First, $0.5 \mathrm{~mol} /$ $\mathrm{LHCl}$ is used to clean and remove the surface oxides, and then deoxidized primary water is used to rinse repeatedly until the $\mathrm{pH}$ of the leach solution is neutral. The $\mathrm{Fe} 0$ used in this experiment is all iron powder with particle size of 150um. Before the experiment, the iron powder was activated. First, the iron powder was cleaned with $0.5 \mathrm{~mol} / \mathrm{L} \mathrm{HCl}$ to remove its surface oxides. Then, the iron powder was repeatedly washed with deoxidized primary water until the $\mathrm{pH}$ of the leach solution was neutral. To avoid air oxidation, the activated iron powder should be used immediately. Factors such as temperature and $\mathrm{pH}$ vary slightly according to the purpose of the experiment, and the specific conditions will be described in detail in the corresponding sections.

\subsection{Analysis method}

In the process of reaction, $\mathrm{pH}$ value was determined by $\mathrm{pH}$ meter. $\mathrm{NH}_{4}{ }^{+}-\mathrm{N}$ was determined by $\mathrm{NaCl}$ reagent spectrophotometry, $\mathrm{NO}_{2}^{-}-\mathrm{N}$ was determined by $\mathrm{N}^{-1}$-naphthalene - ethylenediamine spectrophotometry, $\mathrm{NO}_{3}{ }^{-}$was determined by ultraviolet spectrophotometry,.

\section{Results and analysis}

\subsection{Nitrate denitration under neutral conditions}

In order to explore the effect of adding Anammox bacteria on the reduction of nitrate wastewater by iron powder in neutral environment, we designed a group of control experiments. The $\mathrm{pH}$ values were set as $2,6,7,8$, and the nitrate removal efficiency of the two groups of different substrates in the simulated wastewater was observed( $\mathrm{R} 1: \mathrm{Fe}^{0}, \mathrm{R} 2: \mathrm{Fe}^{0}+$ Anammox $)$. In the initial conditions, influent $\mathrm{NO}_{3}{ }^{-}$concentration was set as 50 $\mathrm{mg} / \mathrm{L}$, iron powder concentration was $5 \mathrm{~g} / \mathrm{L}$, and the temperature was $35^{\circ} \mathrm{C}$. As can be seen from Figure 1, R1 was significantly affected by $\mathrm{pH}$, and the denitration rate was the best under strong acid condition, while R2 showed no significant difference in denitration rate under different $\mathrm{pH}$ conditions. When $\mathrm{pH}=2$, the reduction rate of nitrate in both groups could reach more than $80 \%$, and R2 could hardly detect nitrate after $60 \mathrm{~h}$. However, in neutral environment, the denitration effect of $\mathrm{R} 1$ was not obvious, and with the increase of $\mathrm{pH}$, the denitration rate decreased. When $\mathrm{pH}$ was 8 , the denitrification rate was only $10 \%$. This is because the surface of $\mathrm{Fe}^{0}$ will corrode and produce corrosion products $\mathrm{FeOOH}$ and $\mathrm{Fe}_{3} \mathrm{O}_{4}{ }^{[9]}$. Under acidic conditions, a larger proportion of $\mathrm{Fe}_{3} \mathrm{O}_{4}$ in the product, the loose surface structure of the product has a greater adsorption effect on $\mathrm{Fe}^{2+}$, and the contact area of iron powder is larger, which will promote the reduction of more $\mathrm{NO}_{3}{ }^{-}$ by $\mathrm{Fe}^{0}$. Besides, the reduction of nitrate by iron powder is an acid-driven process. When the concentration of $\mathrm{H}^{+}$ in the system is high, the generated $\mathrm{H}_{2}$ receives more electrons, and a large number of $\mathrm{H}$ atoms on the surface of $\mathrm{Fe}^{0}$ will effectively reduce $\mathrm{NO}_{3}{ }^{-}$. In neutral environment, $\mathrm{Fe}^{0}$ is difficult to corrode but easy to passivate, and it is difficult to generate highly reductive $\mathrm{H}$ atoms. Therefore, the reduction rate of $\mathrm{NO}_{3}{ }^{-}$is greatly reduced.As shown in Figure 2, although the denitration rate in $\mathrm{R} 2$ was inversely proportional to $\mathrm{pH}$, it can all reach more than $88 \%$. The results indicated that Anammox bacteria could improve the nitrate loss in the neutral environment. There are two reasons for this phenomenon: $\square \mathrm{NH}_{4}^{+}$and $\mathrm{NO}_{2}^{-}$as products of the reduction of $\mathrm{NO}_{3}^{-}$by $\mathrm{Fe} 0$, the anaerobic ammonium oxidation reaction occured under the action of Annammox bacteria. By consuming the products, the chemical equilibrium was changed so that the reaction moved forward, resulting in the increase of $\mathrm{NO}_{3}{ }^{-}$loss. $\square$ In addition to the anaerobic ammonium oxidation 
reaction, Anammox bacteria can directly participate in the reduction of $\mathrm{NO}_{3}{ }^{-}$. Some scholars found that Anammox bacteria can use $\mathrm{Fe}^{2+} / \mathrm{Fe}^{0}$ as electron donor to reduce $\mathrm{NO}_{3}{ }^{-}$. In order to explore whether Anammox bacteria can improve the denitration rate through chemical reaction or biochemical dual action, we designed a verification experiment. When $\mathrm{pH}=7, \mathrm{Fe}^{0}$ and zeolite were added, and after $60 \mathrm{mins}$, the nitrate removal rate was $20 \%$. At this time, well-run Anammox sludge was added, and the nitrate removal rate was $80 \%$ after 36h. As shown in Figure 3, in the first stage, zeolite continuously absorbed $\mathrm{NH}_{4}{ }^{+}$generated by $\mathrm{Fe}^{0}$ and $\mathrm{NO}_{3}{ }^{-}$, but the denitration rate did not significantly improve. The experiment showed that the promotion of reaction forward through consumption of products is not the key reason to increase the denitration rate. When $45 \mathrm{mins}$, $\mathrm{NO}_{3}{ }^{-}$was no longer removed, indicating that the chemical reaction between $\mathrm{Fe}^{0}$ and $\mathrm{NO}_{3}{ }^{-}$had stopped. In the second stage, the concentration of $\mathrm{NO}_{3}{ }^{-}$decreased by $29 \mathrm{mg} / \mathrm{L}$ after the addition of Anammox bacteria, indicating that Anammox bacteria directly participated in the reduction of $\mathrm{NO}_{3}{ }^{-}$through biological action.

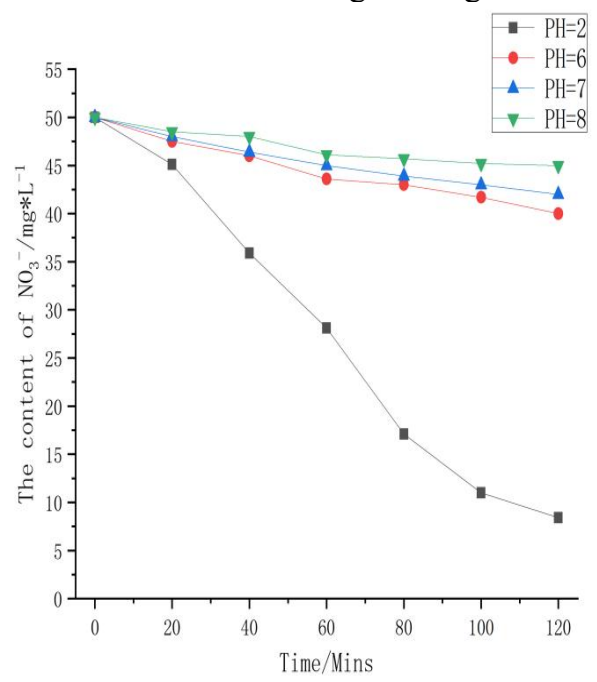

Figure 1. The effect of neutral conditions on nitrate reduction without the participation of Anammox bacteria

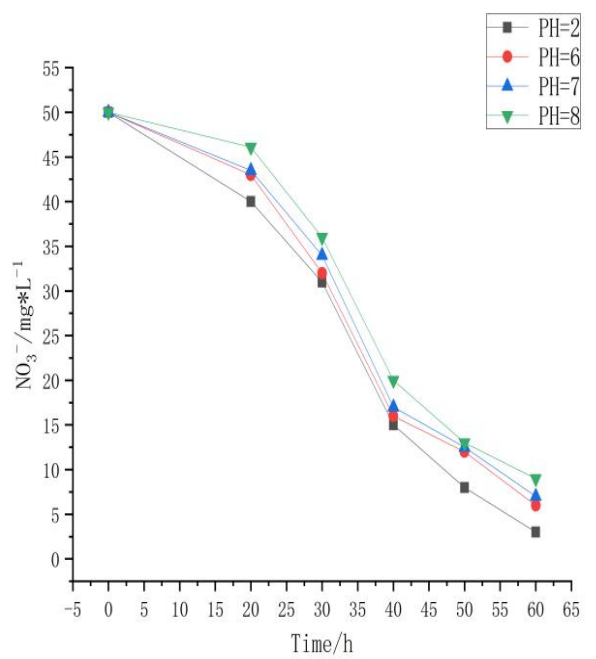

Figure 2. The effect of neutral conditions on nitrate reduction with the participation of Anammox bacteria

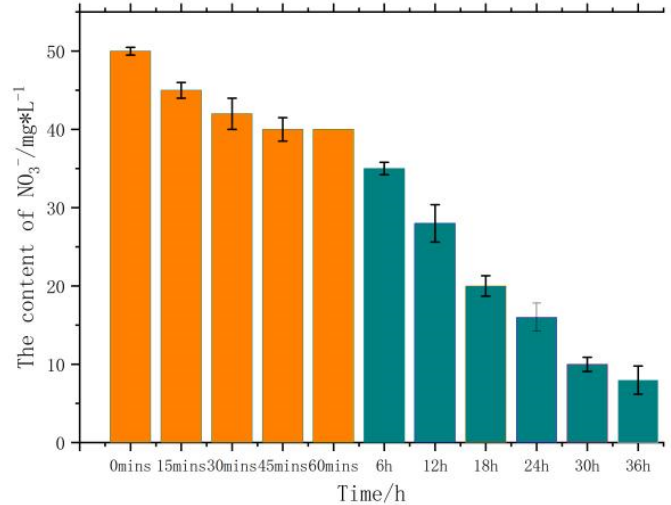

Figure 3. The effect of Anammox bacteria on nitrate reduction rate under $\mathrm{Fe} 0$ /zeolite conditions

\subsection{Fe0/Anammox continuous flow operation experiment}

Batch experiments had verified that $\mathrm{Fe}^{0} /$ Anammox can promote the removal of nitrate in a short period of time, but whether the continuous and stable operation of the reaction can be ensured remains to be studied. Therefore, we carried out continuous flow experiments for further investigation.

The changes in the concentration of each element in the reactor are shown in Figure4. At the initial stage of reaction, the effluent $\mathrm{NO}_{3}^{-}$concentration was high and the removal rate was only $45 \%$. This stage was the adaptation period of Anammox bacteria.From the 5th day to the 12th day, the effluent $\mathrm{NO}_{3}{ }^{-}$concentration was relatively stable, and the denitrification rate was above $70 \%$. From the 13 th day, the concentration of $\mathrm{NO}_{3}{ }^{-}$in the effluent water began to rise, and the nitrate removal rate was only $15 \%$ on the 15 th day. It is worth noting that the concentration of $\mathrm{Fe}^{2+}$ that can be detected in the liquid was proportional to the rate of denitration, and as the rate of denitration decreased, the concentration of $\mathrm{Fe}^{2+}$ in the - system also decreased. For example, the total iron concentration was $192.7 \mathrm{mg} / \mathrm{L}$ on day 10 and decreased to $132.1 \mathrm{mg} / \mathrm{L}$ on day 15 . This indicated that $\mathrm{Fe}^{0}$ was gradually passivated and its nitrate reducing ability was gradually reduced as the reaction proceeded. When the iron powder in the reactor was replaced on the 22nd day, the concentration of $\mathrm{NO}_{3}{ }^{-}$decreased accordingly, and the effluent was about $13 \mathrm{mg} / \mathrm{L}$, On the $30 \mathrm{th}$ day, the concentration of $\mathrm{NO}_{3}{ }^{-}$rose again. The results showed that the stable period of efficient $\mathrm{Fe}^{0}$ treatment was about 7 days, and the reactor began to collapse after this time range. Iron powder was replaced every 7 days from the 35 th day. As shown in Fig. 4, the nitrate removal rate in the reactor from the 35 th day to the 60 th day was stable at around $75 \%$, and the effluent $\mathrm{NO}_{3}{ }^{-}$concentration was even lower than $6 \mathrm{mg} / \mathrm{L}$ on the 60 th day. In summary, the stable period of $\mathrm{Fe}^{0} / \mathrm{Anammox}$ bacteria in treating nitrate in continuous flow was short, and the stable operation of the system can be maintained by replacing iron powder regularly.

The accumulation of $\mathrm{NH}_{4}^{+}$and $\mathrm{NO}_{2}^{-}$can be detected in the whole process, and the changing trend of ammonia nitrogen concentration in the effluent was consistent 
with the changing trend of nitrate removal rate. On day 24-30, the average effluent concentration of ammonia nitrogen was $11.9 \mathrm{mg} / \mathrm{L}$ in the stable phase of nitrate removal. On day 33, the nitrate removal rate was reduced, and the effluent concentration of ammonia nitrogen was reduced to $8 \mathrm{mg} / \mathrm{L}$. On day 35 , it was further reduced to $5 \mathrm{mg} / \mathrm{L}$.On the 38 th day, with the replacement of iron powder, the treatment effect of the system on nitrate was enhanced, and the concentration of ammonia nitrogen increased again. Then, the effluent ammonia nitrogen stabilized at about $12.1 \mathrm{mg} / \mathrm{L}$ on the $38-60$ days. The concentration of nitrite in the whole process was $(2.8 \pm$ $0.3) \mathrm{mg} / \mathrm{L}$, which was consistent with the nitrogen transformation pathway of ${ } \mathrm{NO}_{3}{ }^{-} \rightarrow \mathrm{NO}_{2}{ }^{-} \rightarrow \mathrm{NH}_{4}{ }^{+} "$ proposed by $\mathrm{Li}$ Tielong et al. ${ }^{[10]}$ for the reduction of $\mathrm{NO}_{3}^{-}$by $\mathrm{Fe}^{0}$. When $\mathrm{Fe}^{0}$ was used alone, nitrate will be reduced to a large amount of ammonia nitrogen and nitrite nitrogen, resulting in secondary pollution. Besides, the treatment effect of free ammonia (FA) and nitrite itself inhibiting Anammox in neutral environments is widely recognized ${ }^{[10]}$. In order to maintain the stable operation of the Anammox system, the optimal FA and nitrite concentrations are controlled below $20-25 \mathrm{mg} / \mathrm{L}$ and $100 \mathrm{mg} / \mathrm{L}$, respectively. In this experiment, the effluent FA and nitrite concentrations were far below their respective inhibition thresholds, indicating that the denitrification products did not affect the anaerobic ammonium oxidation reaction activity in the system.

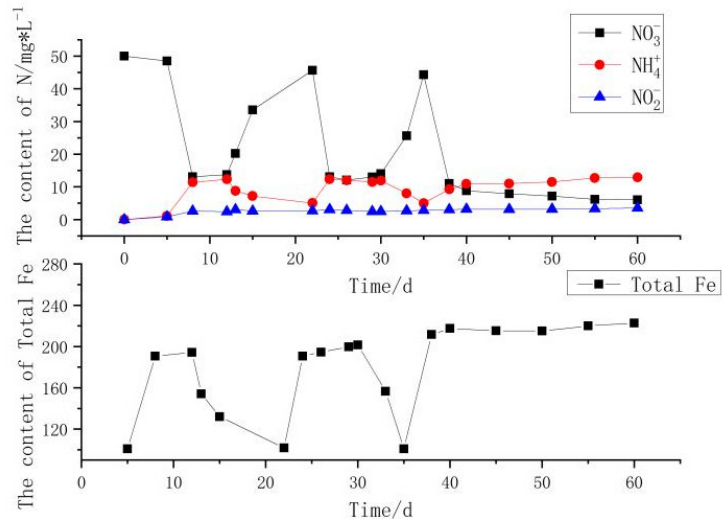

Figure 4. Changes in the concentration of each element in the continuous flow experiment

\section{4 conclusion}

(a) Under neutral conditions, the efficiency of nitrate reduction by Anammox bacteria $/ \mathrm{Fe} 0$ coupling was significantly higher than that of the control group with $\mathrm{Fe}^{0}$ only. The results showed that the enhancement of Anammox bacteria was not related to the change of chemical equilibrium by the consumption of products. The increased nitrogen loss in the experiment was due to the biological reduction of nitrate by microorganisms using $\mathrm{Fe}^{2+}$ dissolved by $\mathrm{Fe}^{0}$.

(b) The nitrate reduction by $\mathrm{Fe}^{0} /$ Anammox bacteria can operate in a continuous flow, but $\mathrm{Fe}^{0}$ is easy to be passivated, which leads to a short stabilization period in the reactor. $\mathrm{Fe}^{0}$ reduces nitrate to produce by-products $\mathrm{NO}_{2}{ }^{-}$and $\mathrm{NH}_{4}{ }^{+}$, which were further reduced to nitrogen under the action of Anammox. Therefore, the concentration of nitrogen by-products in the $\mathrm{Fe}^{0} /$ Anammox reactor was low and the secondary pollution was less.

\section{Fund projects}

1.Study on three-phase synergistic phosphorus recovery mechanism in anaerobic treatment of phosphorus rich wastewater (2019-ZD-0298) , Project of Science and Technology Department of Liaoning Province, 2019,

2.Food waste induces surplus sludge to enhance the fermentation performance of L-lactic acid bacteria (1nqn202011) , Project of Education Department of Liaoning Province, 2020

\section{References}

1. Fan, X.; Guan, X.; Ma, J., et al., Kinetics and corrosion products of aqueous nitrate reduction by iron powder without reaction conditions control.[J] Journal of Environmental Sciences 2009, 21, (8), 1028-1035.

2. Li, X.; Li, J.; Xi, B., et al., Effects of groundwater level variations on the nitrate content of groundwater: a case study in Luoyang area, China.[J] Environmental Earth Sciences 2015, 74, (5), 3969-3983.

3. Zawaideh, L. L.; Zhang, T. C., The effects of $\mathrm{pH}$ and addition of an organic buffer (HEPES) on nitrate transformation in $\mathrm{Fe} 0$-water systems.[J] Water Science and Technology 1998, 38, (7), 107-115.

4. Fan Xiaomeng,Guan Xiaohong,Ma Jun.The mechanism and influencing factors of reducing nitrate in water by zero-valent iron[J].China Water \& Wastewater,2008(14):5-9. (in chinese)

5. Vasudevan, S.; Epron, F.; Lakshmi, J., et al., Removal of NO3- from Drinking Water by Electrocoagulation - An Alternate Approach.[J] CLEAN - Soil, Air, Water 2010, 38, (3), 225-229.

6. Kiskira, K.; Papirio, S.; van Hullebusch, E. D., et al., Influence of $\mathrm{pH}, \mathrm{EDTA} / \mathrm{Fe}$ (II) ratio, and microbial culture on $\mathrm{Fe}(\mathrm{II})$-mediated autotrophic denitrification.[J] Environ Sci Pollut Res Int 2017, 24, (26), 21323-21333.

7. Oshiki, M.; Ishii, S.; Yoshida, K., et al., Nitrate-dependent ferrous iron oxidation by anaerobic ammonium oxidation (anammox) bacteria.[J] Appl Environ Microbiol 2013, 79, (13), 4087-93.

8. Xing, W.; Li, D.; Li, J., et al., Nitrate removal and microbial analysis by combined micro-electrolysis and autotrophic denitrification. [J] Bioresour Technol 2016, 211, 240-7.

9. Hao Zhiwei, Li Liang, Ma Luming. Research on the removal of nitrate in the pipeline by zero-valent iron 
reduction[J]. China Water \& Wastewater, 2008, 24 (17): 36-39. (in chinese)

10. Huang Xiaoming, Lan Yaling, Gao Dongsheng, et al. Research on the Kinetics of Groundwater Nitrate Reduction byZero-valent Iron[J].Environmental Science and Technology,2018,41(12):67-72. (in chinese)

11. Zhang Shude, Li Jie, Yang Hong, et al.. Study on the effect of nitrite on anammox[J].Environmental Pollution \& Control,2005(05):324-326+315. (in chinese) 